\title{
PELAKSANAAN MANAJEMEN KEPALA PERPUSTAKAAN DALAM MENUNJANG KEBERHASILAN PELAYANAN INFORMASI DI DINAS PERPUSTAKAAN DAN ARSIP DAERAH KOTA JAMBI
}

\author{
Oleh \\ Syamsuddin \\ Syam.wid@gmail.com \\ KEPALA PERPUSTAKAAN FAKULTAS SYARI'AH DAN HUKUM \\ UIN SULTHAN THAHA SAIFUDDIN JAMBI
}

\begin{abstract}
This writing aims to express the library manager responsibility as lead in library management through principles of library management. As we know that the information services process at Dinas Perpustakaan dan Arsip Daerah Kota Jambi faced some problems. The problems iclude information technology facilities ; incomplete information retrieval media ; the human resources which less be professional, and fund limitation. The problems are coused by the library manager doesn't has librarianship knowledge and library management ; the library development program that didn't has data to develop library in the next time ; the social relation among bad librarian. The problems can be solved by efforts through conduct the professional organizational coorporation ; support librarians to partcipate erudite activity ; increas fund ; evaluate the program which is not advantage ; use information technology facilities ; make information retrieval media not only manual but also automatic.
\end{abstract}

Key Words: Manajemen, perpustakaan, Arsip, teknologi informasi.

\section{A. Pendahuluan}

Manajemen perpustakaan tidak hanya menyangkut soal administrasi perpustakaan, tetapi menyangkut semua kegiatan perpustakaan, baik yang mengenai materi, personil, perencanaan, kerja sama, kepemimpinan, kepustakawanan (librarianship), dan sebagainya, yang harus diatur untuk menciptakan suasana yang memungkinkan terselenggaranya kondisi pelayanan informasi yang baik guna mencapai tujuan lembaga.

Kegiatan organisasi baik yang bersifat pemerintah maupun swasta, manajemen sangat diperlukan untuk mencapai tujuan yang ditetapkan secara profesional. Manajemen yang efektif adalah yang dapat melihat prinsip-prinsip atau fungsi pokok dalam manajemen, seperti pendapat Taylor dan Fayol yang mengemukakan bahwa prinsip dan fungsi manajemen ialah planning, organizing, commanding, coordination, dan control. ${ }^{1}$ Oleh sebab itu, semua kegiatan institusi

\footnotetext{
${ }^{1}$ George R Terry. Prinsip-prinsip Manajemen. (Jakarta: Bumi Aksara, 2009) hlm. 109
} 
akan dapat berjalan lancar dan berhasil baik jika pelaksanaannya melalui proses yang menurut garis fungsi manajemen perpustakaan.

Menurut Moch. Idochi Anwar, "Penyelenggaraan kegiatan pelayanan informasi sebagai suatu proses memerlukan penanganan yang terencana sistematis agar setiap sumber daya pustakawan maupun staf perpustakaan yang ada dapat dimanfaatkan secara optimal sehingga tercapai efektivitas dan efisien dalam rangka pencapaian tujuan lembaga". ${ }^{2}$ Dalam konteks demikian berarti manajemen perpustakaan akan memadukan berbagai fungsi potensial dan segenap sumber daya lain dan mengintegrasikan sumber daya baik personal maupun material pendidikan melalui kegiatan pengarahan, pengendalian, dan pengolahan yang tepat. Sumber daya terpenting suatu organisasi adalah manusia, yaitu orang-orang yang memberikan tenaga, bakat, kreativitas dan usaha mereka kepada organisasi.

Pustakawan sebagai sumber daya manusia utama di lingkungan PUSDOKUINFO memiliki peran yang sangat strategis dalam pengembangan institusi karena mobilisasi perpustakaan yang mencakup berbagai kegiatan merupakan tanggung jawab moral pustakawan. Karena itu untuk menjadikan institusi lebih baik maka pimpinan harus mampu membuat kebijakan dalam hal pengelolaan sumber daya manusia pustakawan. Salah satu hal yang mendasar dalam aktivitas di perpustakaan adalah pelayanan yang mencakup berbagai layanan yang ada di perpustakaan. Kepala Perpustakaan Dinas Perpustakaan dan Arsip Daerah Kota Jambi sebagai institusi milik pemerintah yang ditunjang dengan berbagai fasilitas yang cukup memadai, sumber daya manusia yang proporsional, dan sistim layanan yang cukup representatif sejatinya sudah menunjukkan sebuah lembaga yang menjadi daya tarik masyarakat dalam akases informasi. Namun pada kenyataannya masih menunjukkan kelemahan baik dari sisi struktural maupun fungsionalnya. Indikasi ini terlihat, Pertama, tingkat kunjungan masyarakat untuk datang ke perpustakaan Dinas Perpustakaan dan Arsip Daerah Kota Jambi tidak mengalami peningkatan yang cukup signifikan. Kedua, penempatan sumber daya manusia di lingkungan Dinas Perpustakaan dan Arsip Daerah Kota Jambi yang tidak sesuai dengan bidangnya. Ketiga, pola

\footnotetext{
${ }^{2}$ Moch. Idochi Anwar, Administrasi Pendidikan dan Manajemen Biaya Pendidikan. (Jakart : Rajawali Presss, 2013), hlm. 71
} 
pembinaan sumber daya manusia pustakawan belum maksimal, indikasi ini terlihat masih adanya pustakawan yang tidak bisa naik pangkat pada waktunya. Keempat, masih adanya keluhan dari pemustaka mengenai sistim layanan yang kurang bersahabat dari pegawai.

\section{B. Kajian Teori}

\section{Pengertian Manajemen Pustakawan}

Sebelum dibahas dan diuraikan pengertian manajemen tenaga pustakawan secara panjang lebar, alangkah baiknya terlebih dahulu kita membahas pengertian manajemen secara umum. ${ }^{3}$ Istilah manajemen sebelumnya dikenal juga dengan istilah administration berasal dari bahasa Latin yang terdiri dari ad intensif dan minitrare suatu kata kerja yang berarti melayani, membantu, mengarahkan. Manajemen adalah suatu proses/ kerangka kerja yang melibatkan bimbingan atau pengarahan suatu kelompok orang-orang ke arah tujuan organisasional atau maksud-maksud yang nyata dan mempunyai 5 fungsi yang fundamental, yaitu :

a. Planning: menentukan tujuan-tujuan yang akan dicapai;

b. Organizing: mengelompokkan dan menentukan berbagai kegiatan penting dan memberikan kekuasaan untuk melaksanakan kegiatan itu;

c. Staffing: menentukan keperluan-keperluan sumber daya manusia, pengerahan, penyaringan, latihan, dan pengembangan tenaga;

d. Motivating: mengarahkan atau menyalurkan perilaku manusia ke arah tujuan-tujuan;

e. Controlling: mengukur pelaksanaan dengan tujaun-tujuan menentukan sebab-sebab penyimpangan-penyimpangan dan mengambil tindakantindakan korektif dimana perlu. ${ }^{4}$

Dilihat dari segi pengertian manajemen pendidikan mempunyai beberapa taksiran yang saling mendukung satu sama lain. The Liang Gie, dan kawankawan, yang dikutip oleh Burhanuddin, mengemukakan bahwa manajemen adalah segenap rangkaian perbuatan penyelenggaraan setiap usaha kerja sama

\footnotetext{
${ }^{3}$ Anonim. Kamus Bahasa Indonesia. (Jakarta: P dan K, 1994), hlm. 271

${ }^{4}$ Sagala Syaiful. Manajemen Strategik Dalam Peningkatan Mutu Pendidikan: Pembuka ruang Kreativitas, Inovasi dan pemberdayaan Potensi Sekolah dalam Sistem Otonomi Sekolah. (Bandung: Al-Fabeta, 2009), hlm. 81
} 
sekelompok manusia untuk mencapai tujuan tertentu. Sondang P. Siagian, yang dikutip oleh Daryanto mengemukakan bahwa manajemen adalah keseluruhan proses kerjasama antara dua orang atau lebih yang didasarkan atas rasionalitas tertentu, untuk mencapai tujuan yang telah ditentukan sebelumnya. ${ }^{5}$

Dari beberapa definisi manajemen yang telah dikemukakan di atas terlihat bahwa dalam setiap kegiatan manajemen terdapat beberapa unsur yang saling berkaitan satu sama lain.

\section{Pengertian Urgensi Manajemen Tenaga Pustakawan}

Pengertian urgensi di dalam Kamus Bahasa Indonesia adalah keharusan yang mendesak, hal yang sangat penting. Jadi urgensi itu sendiri merupakan sesuatu yang penting yang ingin dilakukan hingga mencapai tujuan yang diinginkan. Misalnya manajemen tenaga pustakawan yang merupakan hal terpenting di dalam mencapai tujuan pelayanan, karena tenaga pustakawan merupakan kunci untuk pencapaian tujuan dalam proses pelayanan informasi. ${ }^{6}$

Manajemen sumber daya manusia pustakawan merupakan pengakuan tentang pentingnya tenaga kerja suatu organisasi sebagai sumber daya manusia yang sangat penting dalam memberi kontribusi bagi tujuan-tujuan organisasi, dan penggunaan beberapa fungsi dan kegiatan untuk memastikan bahwa sumber daya manusia pustakawan tersebut digunakan secara efektif dan adil bagi kepentingan individu, organisasi dan masyarakat. Fokus manajemen pustakawan terletak pada upaya mengelola sumber daya manusia pustakawan di dalam dinamika interaksi antara organisasi pekerja yang acapkali memiliki kepentingan berbeda. Menurut Stoner manajemen sumber daya manusia meliputi penggunaan sumber daya manusia secara produktif dalam mencapai tujuan-tujuan organisasi dan pemuasan kebutuhan pekerja secara individual. Stoner menambahkan bahwa karena berupaya mengintegrasikan kepentingan organisasi dan pekerjanya, maka manajemen sumber daya manusia lebih dari sekedar seperangkat kegiatan yang berkaitan dengan koordinasi sumber daya

\footnotetext{
${ }^{5}$ Burhanuddin.Pengantar Manajemen. (Jakarta: Lentera, 2007), hlm. 47

${ }^{6}$ Anonim.Kamus Besar Bahasa Indonesia. (Jakarta: P dan K., 1994), hlm. 1012
} 
manusia organisasi. ${ }^{7}$ Manajemen sumber daya manusia adalah kontributor utama bagi keberhasilan organisasi. Oleh karena itu, jika manajemen sumber daya manusia tidak efektif dapat menjadi hambatan utama dalam memuaskan pekerja dan keberhasilan organisasi.

\section{Bidang Garapan Manajemen Tenaga Pustakawan}

\section{a. Perencanaan}

Perencanaan tenaga pustakawan adalah esensial bagi bidang garapan manajemen itu sendiri, yang mana mulai dari seleksi, hingga pada pemutusan hubungan kerja. Hal ini untuk menggerakkan sebuah lembaga di dalam mencapai tujuan yang diinginkan.

\section{b. Seleksi}

Pengertian seleksi dalam Kamus Bahasa Indonesia berarti juga penyaringan atau pemilihan, jadi seleksi merupakan proses untuk mendapatkan yang paling baik, sedangkan pelaksanaan manajemen personil seleksi adalah metode dan prosedur yang digunakan oleh bagian personil dalam merekrut calon pegawai baru. Tahapan-tahapan seleksi manajemen mencakup seleksi manajemen, ujian/tes, wawancara.

\section{c. Pengangkatan atau Penempatan}

Pengangkatan dan penempatan adalah mengangkat dan menempatkan tenaga-tenaga pustakawan atau pegawai baru pada tempat yang tepat dan kepada mereka yang dipercayakan tugas-tugas yang sesuai dengan keahliannya, karena apabila sesuatu urusan diserahkan kepada yang bukan ahlinya, maka tinggal menunggu kehancurannya. Pengangkatan dan program induksi adalah penempatan karyawan pada suatu jabatan/ pekerjaan baru. Prinsip dari pengangkatan adalah mempertimbangkan efektivitas, peraturan ketenagakerjaan dan menghindari separation. Pengangkatan karyawan dilakukan setelah calon karyawan lulus dalam seleksi dan ditempatkan pada unit yang sesuai dengan kualifikasi yang dimilikinya.

\footnotetext{
${ }^{7}$ Stoner, James, F. Perencanaan dan Pengambilan Keputusan dalam Manajemen. (Jakarta: Rineka Cipta, 1993), hlm. 107
} 


\section{d. Pembinaan}

Pengembangan ketenagaan adalah usaha-usaha untuk meningkatkan mutu serta efesiensi kerja seluruh tenaga yang berada dalam suatu unit organisasi baik tenaga managerial, tenaga teknis edukatif maupun tenaga tata usaha yang memenuhi syarat jabatan yang ada sekarang dan untuk yang akan datang. ${ }^{8}$ Ada juga yang mengartikan bahwa pengembangan personil ialah proses perbaikan prestasi (performance) personil melalui pendekatanpendekatan yang menekankan realisasi diri, pertumbuhan diri, dan perkembangan diri.

\section{e. Penghargaan dan Kesejahteraan}

Penghargaan dan kesejahteraan bagi personil tenaga pustakawan harus diperhatikan. Pemberian penghargaan dan kesejahteraan kepada personil tenaga pustakawan dimaksudkan untuk memotivasi mereka, di samping sebagai imbalan atas kerja mereka pemberian penghargaan dan kesejahteraannya tidak harus berupa materi semata, melainkan melalui pujian, atau sikap yang lemah lembut dengan mereka.

\section{f. Penilaian atau evaluasi}

Evaluasi bermaksud menilai keseluruhan proses kerja dalam mencapai tujuan yang telah dirumuskan. Pelaksanaan evaluasi ini dapat berjalan secara efektif bila dilaksanakan secara kooperatif, agar yang dinilai mengetahui kelemahan dan kekurangan dalam bekerja untuk diperbaiki guna meningkatkan efesiensinya dalam bekerja.

\section{g. Pemutusan Hubungan Kerja}

Pemutusan hubungan kerja dilakukan karena adanya mutasi atau pemindahan kerja, pensiun, meninggal dunia, dan sebagainya. Hal ini dilakukan supaya keterikatan hubungan kerja tidak ada. Pemutusan hubungan kerja dibutuhkan karena untuk penyelesaian akhir masa tugas kerja.

\footnotetext{
${ }^{8}$ Siagian, Sondang P. ManajemenSumber Daya Manusia, (Jakarta: Bumi Aksara, 2001) hlm. 51
} 


\section{Tujuan manajemen tenaga pustakawan}

Tujuan manajemen sumber daya manusia pustakawan di lingkungan PUSDOKUINFO antara lain :

a. Untuk meningkatkan kualitas sistim pelayanan kepada pengguna;

b. Perpustakaan sebagai pusat akses informasi, maka harus menempatkan pustakawan sesuai dengan keahliannya;

c. Pustakawan sebagai tenaga profesional, maka harus pola pembinaan yang tersistimatis dalam upaya meningkatkan karir dan profesinya;

d. Untuk menjadikan pustakawan lebih kompeten terhadap tugas profesinya. ${ }^{9}$

\section{Prinsip-prinsip Manajemen Tenaga Pustakawan.}

Prinsip-prinsip tentu saja diangkat dari prinsip fundamental yang menggunakan pendekatan ilmiah dalam manajemen. Sejauh ini sejumlah prinsip tersebut yang lebih banyak diilhami oleh prinsip manajemen pada umumnya, namun dengan anggapan bahwa dalam prakteknya dapat diterapkan dalam penyelengaraan manajemen tenaga pustakawan.

Dalam menuju tingkat produktivitas penyelenggaraan pelayanan informasi, harus di manajemenkan dengan berpegang pada prinsip-prinsip sebagai berikut:

a. Menerapkan kembali prosedur dan teknik yang dilandasi oleh pengetahuan terorganisir;

b. Mencapai keharmonisan tindakan kelompok, bukan sebaliknya;

c. Mencapai suasana kerja sama manusia bukan individualisasi yang semrawut;

d. Bekerja untuk memperoleh out-put semaksimal mungkin;

e. Mengembangkan para bawahan semaksimal mungkin sesuai dengan segala kemampuan yang ada pada diri dan kemakmuran persatuan mereka sendiri. $^{10}$

Menurut kelima prinsip di atas adalah seperangkat pedoman yang dapat dipegang dalam setiap langkah penyelenggaraan manajemen tenaga pustakawan agar usaha-usaha kepustakawa nan itu mampu mencapai tingkat

\footnotetext{
9 Sutarno NS. Manajemen Perpustakaan:Suatu Pendekatan Praktik, (Jakarta: Samitra Media Utama, 2004), hlm. 78

${ }^{10}$ Stueart, R.D dan Barbara B. Moran. Library and Information Center Management Sixth Edition Westport, (Connecticut: Libraries Unlimited, 2002), hlm. 124
} 
produktivitasnya semaksimal mungkin, yang pada gilirannya tujuan pelayanan informasi itu sendiri dapat tercapai sesuai dengan yang diharapkan.

\section{Metodologi Penelitian}

Penelitian ini merupakan penelitian sosial yang bertujuan untuk mengungkapkan fenomena yang muncul di lapangan. Secara khusus penelitian ini menggamabarkan bagaimana pelaksanaan manajemen tenaga pendidik dalam menunjang keberhasilan pelayanan informasi di Dinas Perpustakaan dan Arsip Daerah Kota Jambi. Penelitian ini berlokasi di Dinas Perpustakaan dan Arsip Daerah Kota Jambi. Penelitian ini menggunakan pendekatan penelitian kualitatif yang bersifat deskriptif. Yakni penelitian yang hanya menggambarkan fenomena apa adanya. Menurut Meleong bahwa penelitian kualitatif deskriptif adalah penelitian yang berusaha untuk mendeskripsikan suatu objek, fenomena atau setting sosial terjewantah dalam suatu tulisan yang bersifat naratif. ${ }^{11}$ Penelitian kualitatif tidak dikenal istilah populasi oleh Spradley dinamakan "social situatuion atau situasi sosial yang terdiri atas tiga elemen yaitu tempat, pelaku dan aktivitas yang berinteraksi secara strategis. ${ }^{12}$ Subjek yang diteliti diambil dengan menggunakan cara purposive sampling yaitu “...teknik yang didasarkan pada ciriciri tertentu diperkirakan erat sangkut pautnya dengan ciri-ciri sifat-sifat yang ada dalam populasi yang sudah diketahui sebelumnya. ${ }^{13}$ Maka yang menjadi key informan dalam penelitian ini adalah kepala perpustakaan, dan selanjutnya yang menjadi responden dalam penelitian ini adalah; pegawai Dinas Perpustakaan dan Arsip Daerah Kota Jambi. Subjek dalam penelitian ini sebagian didatangi dan diwawancarai, dan sebagian lagi didatangi untuk diamati atau diobservasi secara langsung. Hal ini dilakukan untuk penyesuaian informasi atau data yang diperoleh melalui wawancara dengan data yang diperoleh melalui observasi melalui teknik trianggulasi, sehingga data atau informasi yang diperoleh dapat menjadikan valid dan kredibel. Metode pengumpulan data observasi, metode wawancara, metode dokumentasi. Analisis data melalui domain, taksonomi, komponensial. Keabsahan data melalui trianggulasi.

11 Djam'an Satoni dan Aan Komariah. Metodologi Penelitian Kualitatif. (Bandung: Alfabeta, 2010), hlm. 28

${ }^{12}$ Sugiyono.MemahamiPenelitian Kualitatif. (Bandung: Alfabeta, 2005), hlm. 49

${ }^{13}$ Ibid. hlm. 54 


\section{Pelaksanaan Manajemen Tenaga Fungsional Pustakawan di Dinas Perpustakaan dan Arsip Daerah Kota Jambi}

Berdasarkan riset di lapangan, bahwa pelaksanaan manajemen tenaga fungsional pustakawan Dinas Perpustakaan dan Arsip Daerah Kota Jambi dapat dilihat sebagai berikut:

\section{Perencanaan}

Sebagai lembaga fungsional yang berbasis manajemen, tentu mengharapkan mutu tenaga fungsional yang memadai. Karena itu, segala upaya telah dilakukan termasuk dalam melibatkan masyarakat sebagai steakholder dalam merencanakan pengembangan lembaga. Sistim perencanaan yang diterapkan dalam pelaksanaan manajemen fungsional di Dinas Perpustakaan dan Arsip Daerah Kota Jambi adalah melalui beberapa tahap antara lain.

\section{a. Inventaris dokumen Fungsional yang ada}

Pada setiap pegawai atau honorer yang masuk melamar di Dinas Perpustakaan dan Arsip Daerah Kota Jambi harus membuat lamaran yang disertai dengan bukti fisik misalnya Ijazah dan transkrip nilai, pengalaman kerja atau yang lain. Semua fungsional harus memiliki file tersendiri sebagaimana layaknya di lembaga/organisasi lain. Tujuannya adalah untuk memudahkan dalam mendata dokumen ketika dibutuhkan.

\section{b. Rapat di tingkat lingkungan Dinas Perpustakaan dan Arsip Daerah Kota Jambi}

Di lingkungan Dinas Perpustakaan dan Arsip Daerah Kota Jambi, rapat dilakukan pada hari senin karena kegiatan pada hari tersebut tidak sedapat seperti hari-hari lain. Rapat dilakukan ada dua jenis, yakni rapat dengan melibatkan seluruh pegawai dan Fungsional, dan rapat yang hanya diikuti oleh Fungsional saja. Kebijakan untuk melaksanakan rapat baik melibatkan fungsional saja atau melibatkan seluruh pegawai dan fungsional didasarkan pada kebutuhan yang harus diselesaikan atau diprogramkan. Untuk rapat di lingkungan Dinas Perpustakaan dan Arsip Daerah Kota Jambi berdasarkan pada kondisi yang dihadapi Dinas Perpustakaan dan Arsip Daerah Kota Jambi terkait dengan masalah-masalah pegawai, masukan-masukan dari 
masyarakat dan lain-lain. Biasanya dilakaukan rapat pada hari-hari yang tidak begitu sibuk agar tidak mengganggu waktu kerja fungsional maupun kegiatan adminsitrasi para pegawai. Dengan demikian bahwa kegiatan rapat telah dilakukan di lingkungan Dinas Perpustakaan dan Arsip Daerah Kota Jambi dalam upaya mengetahui manajemen tenaga kerja. Rapat di lingkungan Dinas Perpustakaan dan Arsip Daerah Kota Jambi sangat penting mengingat karena lingkungan ini langsung dimonitor mengenai tanggung jawab fungsional dalam melaksanakan tugasnya.

\section{c. Rapat di lingkungan Dinas Perpustakaan dan Arsip Daerah Kota Jambi}

Rapat di lingkungan Dinas Perpustakaan dan Arsip Daerah Kota Jambi merupaan rapat yang diikuti oleh seluruh pengurus Dinas Perpustakaan dan Arsip Daerah Kota Jambi dan staf adminsitrasi sehingga memberikan efek langsung terhadap fungsional selaku pekerja. Efek yang dirasakan adalah fungsional dapat berdialog langsung kepada pihak kepala Dinas Perpustakaan dan Arsip Daerah Kota Jambi apa kendala - kendala yang dihadapi.

Pelaksanaan rapat di lingkungan Dinas Perpustakaan dan Arsip Daerah Kota Jambi dilaksanakan satu kali sebulan, dan bahkan 3 atau 6 bulan sekali tergantung dari keadaan. Tapi menurut keterangan kepala Dinas Perpustakaan dan Arsip Daerah Kota Jambi bahwa pelaksanaan di lingkungan Dinas Perpustakaan dan Arsip Daerah Kota Jambi tergantung dari instruksi pihak Dinas Perpustakaan dan Arsip Daerah Kota Jambi. Jika pelaksanaannya harus satu atau dua kali dalam sebulan kalau itu sifatnya mendesak maka mau tidak mau dilakukan.

Sementara menurut keterangan pihak fungsional sebagai tenaga pustakawan bahwa kegiatan rapat dengan pihak Dinas Perpustakaan dan Arsip Daerah Kota Jambi merupakan waktu yang tepat untuk menyampaikan aspirasi. Sebab kadang ada kalanya kita dihadapkan dengan masalah kewajiban mengajar, bidang studi yang diajarkan. Apalagi kami yang bersertifikasi maka kewajiban kami adalah harus melayani pemustaka dalam setiap hari yang relatif berfluktuasi sementara jumlah personel sangat terbatas. 
Dengan demikian bahwa adanya rapat dengan pihak Dinas Perpustakaan dan Arsip Daerah Kota Jambi dengan melibatkan semua unsur dari Dinas Perpustakaan dan Arsip Daerah Kota Jambi merupakan hal yang menggembirakan, selain itu menunjukkan adanya sikap demokratis pihak Dinas Perpustakaan dan Arsip Daerah Kota Jambi dalam menyelenggarakan fungsionalnya.

\section{Pelaksanaan}

Tahap pertama pemberian atau distribusi pada tugas dan tanggung jawab kepada pegawai sesuai dengan latar belakang pendidikan dan keahliannya. Selanjutnya pegawai dapat memberikan masukan jika ada yang dianggap kurang berkenang pada tugas yang diberikan. Hal ini terjadi karena banyak pegawai yang memiliki latar belakang pendidikan dan tidak sesuai dengan bidang yang diemban.

Tahap selanjutnya, pemberian tugas kepada pegawi untuk melanjutkan kegiatan akademiknya jika ada pegawai yang berminat untuk meningkatkan kompetensinya, atau ada program pengembangan sumber daya manusia dari pihak pemerintah. Menurut kepala Dinas Perpustakaan dan Arsip Daerah Kota Jambi bahwa sudah ada beberapa pegawai yang telah diberi kesempatan untuk mengikuti program ilmiah misalnya bimbingan teknis yang dilaksanakan oleh berbagai instansi namun tetap bertanggung jawab dalam hal kegiatan pelayanan karena merupakan tanggung jawab mereka. Selain itu karena kegiatan ilmiah tersebut dilakukan diluar jam kerja misalnya pada hari Jum'at minggu.

Selajutnya dilakukan pemberian reward atau penghargaan jika pegawai dalam melaksanakan tugasnya dengan baik. Pemberian penghargaan merupakan bentuk untuk meningkatkan motivasi pegawai dalam upaya meningkatkan mutu pelayanan di institusi ini. Penghargaan biasanya diberikan melalui bentuk hadiah, dan pemberian berupa materi karena selain pendapatan pegawai khususnya pegawai honorer yang masih tergolong rendah bagi pegawai yang belum lama bekerja.

Dari serangkaian pelaksanaan manajemen tenaga pengelola perpustakaan di institusi ini menunjukkan keseriusan pihak kepala Dinas Perpustakaan dan 
Arsip Daerah Kota Jambi dalam upaya membenahi sistem maupun sitim pelayanan informasi di lingkungan perpustakaan ini kearah yang lebih berkualitas.

E. Faktor-faktor kendala dalam pelaksanaan manajemen tenaga pengelola perpustakaan/Pustakawan Dinas Perpustakaan dan Arsip Daerah Kota Jambi

\section{Faktor-Faktor Kendala}

\section{a. Keterbatasan Dana}

Dana merupakan tiang penyangga dalam setiap kegiatan, khususnya dilingkungan lembaga PUSDOKUINFO. Tanpa adanya dana akan berdampak pada mobilisasi kegiatan di lingkungan lembaga perpustakaan khususnya di lingkungan Dinas Perpustakaan dan Arsip Daerah Kota Jambi.

Dalam proses manajemen tenaga pengelola perpustakaan juga membutuhakan serangkaian dana mulai tahap perencanaan sampai tahap pelaksanaannya. Namun karena keterbatasan dana membuat program dan pelaksanaan tidak berjalan dengan efektif dan efisien, kalaupun berjalan maka memerlukan kerja keras bagi pihak kepala Dinas Perpustakaan dan Arsip Daerah Kota Jambi beserta elemen-elemennya.

Beberapa kasus yang terjadi disetiap perpustakaan yang hanya mengandalkan dana dari dana DIPA atau APBD belumlah dapat memberikan kontribusi yang berarti dalam pelaksanaan manajemen pelayanan informasi sementara jumlah kegiatan kepustakawanan yang relatif banyak. Manajemen tenaga pengelola perpustakaan sesungguhnya membutuhkan keseriusan masalah dana, beberapa kasus di PUSDOKUINFO masalah dana merupakan masalah yang menjadi serius, karena terkait dengan masalah honor staf administrasi. Sebab kegiatankegiatan penginventarisan dikerjakan oleh staf administrasi. Begitu juga dengan pengembangan sumber daya manusia, maupun evaluasi dengan memberikan reward bagi pegawai yang dianggap sukses dalam melasanakan tugasnya. 


\section{b. Kondisi sosial Sumber Daya Manusia yang ada}

Masalah sumber daya manusia merupakan salah satu faktor yang sangat penting dalam upaya meningkatkan kualitas mutu pelayanan dan pada akhirnya akan bermuara pada pembangunan bangsa. Putakawan sebagai bagian dari builder nation memiliki andil yang cukup besar dalam membentuk sikap dan prilaku maupun kecerdasan masyrakat melalui kultur membaca di perpustakaan. Karena itu dibutuhkan kehadiran pustakawan yang memiliki kemampuan manajemen dalam arti kemampuan dalam mengelola layanan referensi, mengelola referensi dan manajemen perpustakaan lain. Selain itu, juga dibutuhkan dedikasi yang kuat dalam menunaikan tugasnya sehingga dalam melaksanakan tugasnya pustakawan tidak saja mempersepsikan tugas sebagai lahan untuk mencari nafkah tetapi juga sebagai lahan pengabdian pada agama, bangsa dan negara.

Untuk mengelola manajemen tenaga pengelola perpustakaan yang profesional di lingkungan Dinas Perpustakaan dan Arsip Daerah Kota Jambi dibutuhkan berdasarkan konsep di atas. Di lapangan menunjukkan bahwa kendala berupa dukungan staf adminsitrasi dan sebagian pegawai/pustakawan menjadi kendala bagi kepala Dinas Perpustakaan dan Arsip Daerah Kota Jambi dalam melakukan manajemen tenaga pengelola perpustakaan/pustakawan. Hal ini tercermin dalam pengelolaan arsip dan dokumentasi yang tidak dikelola dengan profesional. Misalnya ada beberapa dokumentasi yang tidak dikelola sesuai dengan tempatnya, dan tidak diurut berdasarkan jenis dan subjeknya. Kondisi seperti ini seringkali membuat bingung bagi staf adminsitrasi ketika kepala Dinas Perpustakaan dan Arsip Daerah Kota Jambi membutuhkan informasi mengenai data-data dokumentasi.

\section{c. Kompetensi Manajemen Kepala Dinas Perpustakaan dan Arsip Daerah Kota Jambi}

Peran kepala Dinas Perpustakaan dan Arsip Daerah Kota Jambi sebagai pimpinan tertinggi di lingkungan Perpustakaan sangat menentukan arah pengembangan lembaga kedepan. Kepala harus mampu memahami segala kemungkinan-kemungkinan yang dapat mempengaruhi kebijakan 
lembaga, karena itulah dibutuhkan kemampuan manajemen strategis sebagai bagian dari persyaratan untuk menjadi pemimpin.

Dalam mengembangkan manajemen tenaga fungsional pustakawan di lingkungan Dinas Perpustakaan dan Arsip Daerah Kota Jambi umumnya akan berhadapan dengan masalah profesionalitas pustakawan. Hal ini disebabkan karena pustakawan yang mengajar tidak relevan dengan kompetensi yang diemban.

Di lingkungan Dinas Perpustakaan dan Arsip Daerah Kota Jambi umumnya adalah pegawai yang berlatar belakang pendidikan bukan sarjana ilmu perpustakaan sementara yang berlatar belakang ilmu perpustakaan hanya tiga orang itupun masih honorer. Akibatnya ada pegawai yang menangani kegiatan kepustakawanan sehingga berdampak pada kualitas pelayanan dan pengolahan bahan perpustakaan. Hal ini seperti yang sering menjadi keluhan bagi kepala Dinas Perpustakaan dan Arsip Daerah Kota Jambi bahwa kita membutuhkan kualitas lembaga lebih berkualitas dan profesional namun disisi lain kita terbatas jumlah personil yang profesional.

\section{Faktor-Faktor Pendukung}

\section{a. Motivasi Pegawai/Pustakawan}

Dalam upaya mewujudkan manajemen tenaga pegawai/pustakawan di lingkungan Dinas Perpustakaan dan Arsip Daerah Kota Jambi adalah adanya motivasi yang dimiliki oleh pegawai/pustakawan dalam menunaikan tugasnya. Motivasi merupakan unsur yang paling mendasar dalam setiap individu untuk mencapai harapan yang telah diprogramkan.

Dalam kontek penerapan manajemen tenaga pegawai/pustakawan khususnya di lingkungan Dinas Perpustakaan dan Arsip Daerah Kota Jambi kepala didukung oleh pegawai/pustakawan yang memiliki dedikasi pengabdian. Pegawai tidak perlu didorong untuk melaksanakan tugasnya, namun kesadaran mereka terhadap lembaga sungguh hal membanggakan. Ini terlihat misalnya pada saat awal tahun, para pegawai/pustakawan sendiri dalam membuat tugas-tugas atau hal-hal yang terkait dengan manajemen pelayanan perpustakaan. Kepala Dinas Perpustakaan dan Arsip Daerah Kota Jambi dalam hal ini hanya menerima laporan saja, dan proses 
operasionalnya dilakukan oleh para pegawai/pustakawan dan staf adminsitrasi.

Setiap hambatan yang dihadapi harus bercermin dari setiap kebijakan yang diterapkan sehingga dapat dipahami secara bersama. Hambatan-hambatan berupa lemahnya motivasi pegawai/pustakawan dalam melaksanakan tugasnya merupakan suatu indikasi adanya suatu kebijakan yang tidak proporsional dan mesti disikapi oleh kepala Dinas Perpustakaan dan Arsip Daerah Kota Jambi sebagai penentu kebijakan.

\section{b. Dukungan Pemerintah dan Masyarakat}

Sebagai lembaga yang berorientasi pada pelayanan jasa, tentu membutuhkan banyak pegawai yang profesional dalam upaya mendapat apresiasi dari masyarakat dan pemerintah. Hal ini disebabkan karena jumlah pekerjaan yang lebih banyak. Dengan jumlah seperti ini secara langsung mempengaruhi sistim manajemen tenaga pegawai, artinya semakin banyak pegawai semakin banyak pula kebutuhan yang harus diakomodir.

Namun demikian bahwa, bukan berarti dalam pelaksanaan manajemen menjadi kendala utama, akan tetapi dukungan moril maupun materil dari pemerintah dan masyarakat tidak berpihak sebab terkadang masyarakat itu sendiri bergeming dengan kualitas perpustakaan. Dari pihak pemerintah, respon terhadap keberadaan perpustakaan dalam hal ini Dinas Perpustakaan dan Arsip Daerah Kota Jambi masih terbatas pada dukungan moril, bantuan dana bantuan operasional, dan bantuan-bantuan lain masih minim. Kondisi seperti ini berpengaruh pada manajemen tenaga pegawai karena proses manajemen identik dengan kegiatan perencanaan yang didukung dengan fasilitas. Misalnya kita belum mendapatkan bantuan fasilitas dari pihak pemerintah, meskipun telah ada kesempatan yang diberikan kepada pegawai untuk mengikuti kegiatan workshop kepustakawanan. Manajemen terkait dengan kegiatan administrasi sehingga dalam implementasinya di lapangan dibutuhkan suatu sarana dan prasarana yang memadai. 


\section{c. Keterbukaan pihak Pemerintah}

Salah satu kendala yang dihadapi oleh pihak Pemerintah dalam pelaksanaan manajemen tenaga pegawai adalah transparansi atau keterbukaan pihak Dinas Perpustakaan dan Arsip Daerah Kota Jambi terhadap pihak pustakawan maupun staf administrasi masih kurang. Hal ini diakui oleh beberapa pegawai maupun pihak administrasi misalnya kebijakan penerimaan pustakawan maupun staf administrasi yang tidak ada koordinasi dengan pihak Dinas Perpustakaan dan Arsip Daerah Kota Jambi maupun instansi lain. Kebijakan seperti ini menurut keterangan pustakawan akan berdampak pada distribusi tugas pelayanan yang diemban oleh masingmasing pustakawan maupun staf administrasi.

Selanjutnya menurut keterangan kepala perpustakaan bahwa proses rekrutmen tenaga pustakawan harus melalui sebuah rapat koordinasi di lingkungan perpustakaan dengan melibatkan semua unsur pengelola (pustakawan, pimpinan dan staf administrasi) kemudian dikoordinasikan dengan pemerintah Kota Jambi untuk ditindak lanjuti, dengan cara seperti ini akan lebih demokratis sebab selain adanya informasi yang masuk ke pihak perpustakaan maupun pihak pemerintah sebagai pemegang otoritas dalam hal pengembangan pegawai negeri.

\section{F. Upaya-upaya untuk mengatasi kendala-kendala dalam Pengelolaan} Manajemen Perpustakaan Dinas Perpustakaan dan Arsip Daerah Kota Jambi

\section{Kerjasama dengan Assosiasi maupun Organisasi Profesional Pustakawan}

Dinas Perpustakaan dan Arsip Daerah Kota Jambi dalam kiprahnya sebagai intitusi yang berorientasi pada pelayanan jasa membutuhkan hubungan sosial maupun politik dengan organisasi lain yang menaungi aktifitas pustakawan misalnya Ikatan Pustakawan Indonesia maupun Assosiasi Perpustakaan Sekolah, dan Forum Perpustakaan Perguruan Tinggi Indonesai (FPPTI) yang ada di kota Jambi. 
Salah satu faktor pentingnya Dinas Perpustakaan dan Arsip Daerah Kota Jambi menjalin kerjasama dengan assosiasi tersebut di atas, adalah kebutuhan informasi perkembangan dunia kepustakawanan termasuk dalam hal pengelolaan perpustakaan. Dinas Perpustakaan dan Arsip Daerah Kota Jambi tidak bisa menutup diri dengan dunia perpustakaan lain sebab perpustakaan membutuhkan kerjasama antar perpustakaan yang sudah sebagian besar dilakukan oleh berbagai jenis perpustakaan. Hal ini sebagaimana dikemukakan oleh Kepala Dinas Perpustakaan dan Arsip Daerah Kota Jambi.

Selain menjalin hubungan kerjasama dengan organisasi profesional perpustakaan, Dinas Perpustakaan dan Arsip Daerah Kota Jambi juga menjalin hubungan kerjasama dengan instansi pemerintah di lingkungan Kota Jambi. Kerjasama ini menyangkut masalah birokrasi agar perpustakaan memahami mengenai kebijakan-kebijakan yang terbaru dari pemerintah. Sebagai lembaga milik pemerintah, Dinas Perpustakaan dan Arsip Daerah Kota Jambi juga telah berkontribusi dalam pengembangan pustakawan di instansi pemerintah.

Kerjasama yang lebih profesional juga dapat berpengaruh terhadap kualitas lembaga sebab semakin lebih membuka diri untuk sharing informasi dengan institusi lain akan semakin memberikan ruang kepada lembaga dalam mengembangkan diri. Selain itu, kepala perpustakaan dan sumber daya manusia yang ada juga akan semakin cekatan dalam melaksanakan tugas dan tanggung jawabnya. Tidak ada alasan bagi perpustakaan untuk berdalih bahwa jika tidak ditunjang dengan dana akan semakin mempersempit ruang pengembangan institusi sebab dengan menjalin hubungan dengan organisasi profesional di atas sesungguhnya tidak membutuhkan dana. Karena itu, dibutuhkan kreatifitas dan daya juang bagi pimpinan maupun pustakawan dalam upaya meningkatkan kualitas manajemen pengelolaan perpustakaan.

\section{Kerjasama dengan pihak Pemerintah}

Sebagai lembaga pendidikan yang berorientasi pengembangan sumber daya manusia, maka Dinas Perpustakaan dan Arsip Daerah Kota Jambi senantiasa menjalin hubungan kerjasama dengan pihak pemerintah dan swasta. Tujuannya adalah untuk membantu manajemen perpustakaan agar mutu pelayanan informasi dapat meningkatkan sesuai dengan harapan. 
Bercermin dari beberapa kendala yang dihadapi oleh lembaga ini, maka salah satu jawaban dari upaya untuk mengatasi adalah menjalin kerjasama dengan pemerintah. Pemerintah senantiasa mencurahkan perhatiannya terhadap setiap lembaga yang berkeinginan untuk membangun lembaga yang lebih profesional. Karena itu, kerjasama yang diharapkan oleh Dinas Perpustakaan dan Arsip Daerah Kota Jambi adalah terkait dengan peningkatan mutu sumber daya manusia pustakawan dan staf adminsitrasi, bantuan operasional lembaga, bantuan fasilitas perpustakaan dan lain-lain.

Meskipun telah ada beberapa tawaran dari pihak pemerintah, namun kerjasama berupa pengembangan mutu sumber daya manusia pustakawan dan staf adminsitrasi, dan bantuan berbagai koleksi cetak maupun non cetak. Dalam kerjasama peningkatan mutu pustakawan dan staf administrasi, pihak perpustakaan telah mengirim beberapa pustakawan dan staf administrasi mengikuti kegiatan workshop yang dilakukan oleh Kementerian Agama RI dan Kementerian Pendidikan Nasional Kabupaten Provinsi dan Kota Jambi. Kegiatan ini paling tidak dapat membantu para pustakawan dalam melaksanakan tugas dan tanggung jawabnya di bidang kepustakawanan. Sebagai tenaga profesional, pustakawan diharapkan senantiasa memiliki wawasan dan pengetahuan perpustakaan yang mumpuni sehingga dalam setiap masalah yang terkait dengan pengembangan perpustakaan dapat diatasi. Pustakawan senantiasa harus didorong untuk proaktif dalam mengikuti perkembangan kebijakan pemerintah sehingga dapat berkontriubusi terhadap lembaga. Upaya-upaya ini jelas dapat berpengaruh terhadap manajemen tenaga perpustakaan, sehingga dalam setiap penyusunan program kerja tidak menemui kendala.

\section{Peningkatan Akses Informasi}

Salah satu faktor yang paling dibutuhkan dalam dunia pendidikan adalah kemampuan akses informasi baik dari kalangan pustakawan, pegawai maupun sumber daya manusia lain. Akses informasi seringkali mencakup berbagai pengetahuan yang dapat mendukung dalam kegiatan kepustakawanan, dan akses informasi terkait dengan masalah kebijakan. 
Lemahnya akses informasi di kalangan pustakawan maupun Dinas Perpustakaan dan Arsip Daerah Kota Jambi itu sendiri lebih disebabkan karena; minimnya fasilitas teknologi informasi yang dimiliki pihak institusi, metode untuk mendapatkan informasi yang tidak efektif misalnya informasi diperoleh secara lisan dari orang ke orang. Akses informasi seringkali identik dengan teknologi informasi semisal internet agar dapat memudahkan dalam pelaksanaan pelayanan perpustakaan. Di lembaga ini, upaya yang telah dilakukan adalah masih hanya sebatas media komputer dan laptop, sementara untuk mendapatkan informasi internet harus keluar ke internet. Fasilitas internet harus ada agar dapat membantu manajemen pendidikan khususnya dalam melaksanakan manajemen pustakawan agar dapat membantu proses pelayanan informasi. Namun bukan berarti kemampuan akses informasi hanya sebatas pada pengaksesan informasi melalui media internet tetapi juga kemampuan dalam mendapatkan berita melalui media cetak. Karena itulah pihak Dinas Perpustakaan dan Arsip Daerah Kota Jambi telah berlangganan salah satu surat kabat yang dapat membantu para pustakawan maupun staf pegawai dalam melaksanakan manajemen pustakawan.

\section{Pelaksanaan rapat}

Pelaksanaan rapat di lingkungan Dinas Perpustakaan dan Arsip Daerah Kota Jambi dilakukan dua kali dalam sebulan untuk memantau perkembangan proses pelayanan informasi di setiap lini layanan, memantau perkembangan pustakawan dalam melaksanakan tugasnya dan perkembangan-perkembangan lain. Meskipun belum ada regulasi yang mengatur di Dinas Perpustakaan dan Arsip Daerah Kota Jambi ini tentang pelaksanaan rapat secara tertulis, namun oleh Dinas Perpustakaan dan Arsip Daerah Kota Jambi membuat kebijakan secara lisan kepada semua pustakawan dan staf administrasi termasuk mengundang pihak institusi untuk menginformasikan masalah pelaksanaan manajemen tenaga pustakawan perpustakaan ini.

Pelaksanaan rapat ini sesungguhnya sudah dimulai sejak bulan Juli diawali ide dari pustakawan, karena selama ini hubungan dan komunikasi antara pimpinan dan staf jarang sekali. Perkembangan di lingkungan perpustakaan perlu ada sharing informasi sehingga tidak menjadi hambatan 
pada saat penentuan mata pelajaran bagi pustakawan. Hubungan yang lebih komunikatif antara Dinas Perpustakaan dan Arsip Daerah Kota Jambi dengan pustakawan maupun dengan staf administrasi diharapkan selalu membawa perubahan yang lebih positif pada perpustakaan.

Pelaksanaan rapat ini juga pada hakikatnya merupakan tindak lanjut dari program perencanaan pengembangan perpustakaan. Komitmen Dinas Perpustakaan dan Arsip Daerah Kota Jambi dan pustakawan maupun staf administrasi dalam meningkatkan mutu manajemen perpustakaan tercermin dari pelaksanaan manajemen pengelolaan perpustakaan. Hal ini dikarenakan pustakawan merupakan unsur yang paling penting karena terkait dengan proses pelayanan informasi di perpustakaan.

\section{Melaksanakan Survei Terhadap Kepuasan Pemustaka}

Evaluasi pelaksanaan tugas merupakan suatu proses penilaian atas tindakan masa lalu yang memiliki kekuatan sebagai umpan balik dan bersifat berkesinambungan yang berguna untuk meningkatkan produktivitas masa yang akan datang. Hasil evaluasi pelaksanaan tugas akan menghasilkan informasi mengenai pelaksanaan tugas dalam hubungannya dengan tujuan/sasaran. Dengan melakukan evaluasi pelaksanaan tugas, perpustakaan dapat melihat keberhasilan atau kegagalannya.

Guna mengetahui tingkat kepuasan pemustaka terhadap sistim pelayanan perpustakaan di Dinas Perpustakaan dan Arsip Daerah Kota Jambi dapat dilakukan dengan melaksanakan survei kepuasan pemustaka. Hal ini dapat dilakukan dengan menyediakan kuestioner dan dibagian kepada pemustaka yang datang di perpustakaan atau dilakukan dengan jemput bola dengan mendatangi lokasi-lokasi aktivitas utama pemustaka. Karena berhubungan dengan kepuasan pemustaka terhadap manajemen pelayanan perpustakaan otomatis berkaitan juga dengan kualitas sumber daya manusia dalam memberikan pelayanan. Karena itu, perlu mengetahui titik-titik layanan yang akan menjadi objek evaluasi, misalnya: layanan sirkulasi, layanan referensi, layanan closed reserve, layanan terbitan berkala, dan sebagainya. 


\section{Melakukan Analisis Situasi}

Sebelum membuat strategi pemasaran, pengelola perpustakaan atau pustakawan harus memahami lingkungan yang ada saat ini dan lingkungan potensial yang menjadi garapan jasa layanan perpustakaan. Analisis situasi bisa juga disebut dengan analisis SWOT, untuk itu perpustakaan harus mengidentifikasi kekuatan (Sthrength) dan kelemahan (Weaknesess) internalnya, serta juga mengkaji peluang (Oppotunities) dan ancaman (Threats) dari eksternal perpustakaan.

Menganalisis kekuatan dan kelemahan internal perpustakaan, maka pengelola perpustakaan dan pustakawan harus memusatkan perhatiannya pada sumber daya organisasi, seperti sumber keuangan, biaya operasional, kelembagaan, ketersediaan dan kemampuan Sumber Daya Manusia, citra perpustakaan, ketersedian teknologi, dan lain sebagainya. Sedangkan pada saat menganalisis peluang dan ancaman eksternal, pengelola perpustakaan dan pustakawan harus menganalisis aspek-aspek lingkungan pemasaran, seperti sosial, demografi, teknologi, ekonomi dan faktor lingkungan makro lainnya. Proses inilah yang biasa disebut dengan pemindaian lingkungan. Pemindaian lingkungan membantu mengidentifikasi peluang maupun ancaman bagi perpustakaan dan memberikan arahan dalam mendesain strategi peningkatan kualitas manajemen pelayanan di perpustakaan.

Ketika menganalisis peluang dan ancaman yang datang dari ekternal perpustakaan, maka kita telah menjalankan analisis situasi lembaga sebagaimana yang biasa dilaksanakan oleh institusi lain khususnya pada PUSDOKUINFO. Penilaian situasi meliputi pendefenisian dan penganalisaan faktor-faktor internal dan eksternal. Pada saat membuat rencana program peningkatan kualitas manajemen pengelolaan perpustakaan, maka terlebih dahulu kita redefinition jenis-jenis layanan yang ada, sumber daya manusia perpustakaan, anggaran institusi dan kondisi objektif lain yang berkaitan dengan perpustakaan. Agar mengerti dan memudahkan dalam mengambil kebijakan strategis pengembangan kualitas lembaga. penganalisaan lingkungan internal lembaga meliputi kegiatan-kegiatan sebagai berikut : 
a. Mengidentifikasi layanan-layanan baru yang dapat meningkatkan kepuasan pemustaka dan meningkatkan kunjungan kelompok sasaran;

b. Mengevaluasi layanan-layanan perpustakaan yang sudah ada sebagai pedoman strategi;

c. Mengamati kecendrungan keinginan dan kebutuhan informasi kelompok sasaran.

Langkah selanjutnya analisis eksternal lembaga. Analisis ini merupakan strategi yang sangat penting dalam mengembangkan program peningkatan kualitas manajemen pengelolaan perpustakaan, diharapkan usaha-usaha yang dilakukan dapat mencapai tujuan institusi secara efektif dan efisien. Perpustakaan perlu memastikan kembali segmentasi perpustakaannya, dengan kata lain perpustakaan perlu mengetahui siapa sebenarnya yang berkepentingan menikmati layanan perpustakaan yang disediakannya. Kelompok pengguna mana sebenarnya sasaran layanan perpustakaan.

\section{Promosi Jasa Perpustakaan}

Promosi merupakan faktor penentu keberhasilan program pengembangan perpustakaan. Walaupun produk yang dihasilkan berkualitas, tetapi masyarakat belum pernah mendengar atau mengetahuinya dan tidak yakin bahwa produk tersebut berguna bagi mereka, maka mereka tidak akan pernah menggunakannya. Pada hakikatnya promosi adalah suatu bentuk komunikasi pemasaran, dimana yang dimaksud dengan komunikasi pemasaran adalah aktivitas pemasaran yang berusaha menyebarkan informasi, mempengaruhi/membujuk, dan/atau mengingatkan masyarakat atas perpustakaan dan produknya agar memahami keberadaan perpustakaan sebagai lembaga yang menyediakan berbagai sumber-sumber informasi sekaligus dapat membantu mereka dalam meningkatkan pengetahuan dan wawasan akan berbagai pengalaman hidup.

Selama ini, proses evaluasi diri lebih bertumpu pada penilaian internal lembaga sehingga cenderung menghasilkan nilai yang subjektifitas. Misalnya perpustakaan sudah dianggap baik padahal belum ada respon dari masyarakat sebagai pengguna. Perpustakaan tidak pernah terfikirkan bagaimana kebutuhan masyarakat, bagaimana sistim pelayanan yang mereka rasakan, dan bagaimana hubungan sosial dengan pustakawan dalam memberikan pelayanan. Elemen- 
elemen ini menjadi faktor terpenting dalam upaya meningkatkan kualitas manajemen pengelolaan Dinas Perpustakaan dan Arsip Daerah Kota Jambi.

\section{G. Kesimpulan}

Pelaksanaan Manajemen Tenaga Pustakawan dan pegawai pengelola perpustakaan di Dinas Perpustakaan dan Arsip Daerah Kota Jambi melalui perencanaan yang mencakup; mengiventaris dokumen-dokumen pegawai, melaksanakan rapat di tingkat lingkungan perpustakaan, dan mengikuti rapat di lingkungan Satuan Kerja Perangkat Daerah (SKPD). Sedangkan pelaksanaannya di lapangan berdasarkan perencanaan yang telah dibuat. Faktor-faktor kendala dalam pelaksanaan manajemen tenaga Pustakawan dan pegawai pengelola perpustakaan di Dinas Perpustakaan dan Arsip Daerah Kota Jambi adalah; keterbatasan dana, kondisi sosial sumber manusia yang masih kurang, dan kemampuan manajemen kepala Dinas Perpustakaan dan Arsip Daerah Kota Jambi. Sedangkan faktor-faktor pendukung adalah ; motivasi pustakawan, dukungan pemerintah dan masyarakat, keterbukaan pihak Kepala maupun elemen-elemen lain. Adapun upaya yang dilakukan untuk mengatasi kendala pelaksanaan manajamen tenaga adalah kerjasama dengan pihak pemerintah dalam hal dukungan dana, berpartisipasi dalam hal kegiatan ilmiah seperti seminar, diklat dan lain-lain, peningkatan akses informasi untuk mengetahui perkembangan manajemen tenaga pegawai/pustakawan yang profesional, dan pelaksanaan rapat yang insentif; melaksanakan evaluasi berupa survei terhadap kepuasan pemustaka yang mencakup melakukan analisis situasi dan promosi jasa perpustakaan.

\section{DAFTAR PERPUSTAKA}

Anonim. Kamus Bahasa Indonesia. (Jakarta: P dan K, 1994)

Anonim. Kamus Besar Bahasa Indonesia. (Jakarta: P dan K, 1994)

Burhanuddin. Pengantar Manajemen. (Jakarta: Lentera, 2007)

Djam'an Satoni dan Aan Komariah. Metodologi Penelitian Kualitatif. (Bandung: Alfabeta, 2010) 
Dalimunthe, Ritha F. "Keterkaitan Antar Penelitian Manajemen dengan Pendidikan dan Pengembangan Ilmu Manajemen”. Diakses pada tanggal 11 April 2016 dari http://library.usu.ac.id/download/fe/manajemen-ritha1.

George R Terry. Prinsip-prinsip Manajemen. (Jakarta: Bumi Aksara, 2009)

Moch. Idochi Anwar, Administrasi Pendidikan dan Manajemen Biaya Pendidikan. (Jakarta: Rajawali Presss, 2013)

Moleong, Lexy J.. Metodologi Penelitian Kualitatif, (Bandung: Remaja Rosdakarya, 2004)

Sagala Syaiful. Manajemen Strategik dalam Peningkatan Mutu Pendidikan : Pembuka Ruang Kreativitas, Inovasi dan pemberdayaan Potensi Sekolah dalam Sistem Otonomi Sekolah. (Bandung: Al-Fabeta, 2009)

Siagian, Sondang P. Manajemen Sumber Daya Manusia, (Jakarta: Bumi Aksara, 2001)

Sihotang, A. Manajemen Sumber Daya Manusia, (Jakarta: Pradnya Paramita, 2007)

Stoner, James, F. Perencanaan dan Pengambilan Keputusan dalam Manajemen. (Jakarta: Rineka Cipta, 1993)

Stueart, R.D dan Barbara B. Moran. Library and Information Center Management Sixth Edition Westport, (Connecticut: Libraries Unlimited, 2002)

Sugiyono. Memahami Penelitian Kualitatif. (Bandung: Alfabeta, 2005)

Sutarno NS. Manajemen Perpustakaan: Suatu Pendekatan Praktik, (Jakarta: Samitra Media Utama, 2004)

Winardi. Teori Organisasi dan Pengorganisasian, (Jakarta: RajaGrafindo Persada, 2003) 